\section{New Methodology to Evaluate Bond Strength of Root-End Filling Materials}

Jorge Henrique Stefaneli Marques', Yara Teresinha Corrêa Silva-Sousa ${ }^{1}$, Fuad Jacob Abi Rached-Júnior ${ }^{1}$, Jardel Francisco Mazzi-Chaves ${ }^{2}$, Carlos Eduardo Saraiva Miranda', Silvio Rocha Correa da Silva1, Liviu Steier³, Manoel Damião Sousa-Neto²
School of Dentistry, UNAERP Universidade de Ribeirão Preto, Ribeirão Preto, SP, Brazil ${ }^{2}$ School of Dentistry of Ribeirão Preto, USP - Universidade de São Paulo, Ribeirão Preto, SP, Brazil ${ }^{3}$ Warwick Medical School, The University of Warwick, Coventry, UK

Correspondence: Prof. Dra. Yara T. Correa Silva Sousa, Rua Célia de Oliveira Meireles, 350, Jardim Canada, 14024-070 Ribeirão Preto, SP, Brazil. Tel: +55-16-36036717. e-mail:ysousa@unaerp.br
This study evaluated the bond strength of root-end filling materials to root-end cavities using a new methodology. Twenty maxillary central incisors were subjected to biomechanical preparation (\#80 hand file) and sectioned transversally $2 \mathrm{~mm}$ short of the apex and $4 \mathrm{~mm}$ coronally to this point. The root cylinders were embedded in acrylic resin and positioned at $45^{\circ}$ to the horizontal plane for preparation of root-end cavities with a diamond ultrasonic retrotip. Two groups $(n=10)$ were formed according to the root-end filling material: MTA and Super EBA. A gutta-percha cone (\#80) was tug-backed at the limit between the canal and the root-end cavity. The cavity was filled and the gutta-percha cone was removed after complete setting of the sealer. The specimens were placed in an Instron machine with the root-end filling turned downwards. The push-out shaft was inserted in the space previously occupied by the gutta-percha cone and run at a crosshead speed of $1.0 \mathrm{~mm} / \mathrm{min}$ for pushing out the root-end filling material. Data were analyzed by ANOVA $(\alpha=5 \%)$. Super EBA $(6.03 \pm 1.31)$ presented higher bond strength (MPa) than MTA $(1.81 \pm 0.45)(p>0.05)$. There was a predominance of cohesive failures for Super EBA and mixed for MTA. The protocol of specimen preparation is effective and introduces a specific methodology for assessing bond strength of root-end filling materials to dentin. Among the materials, Super EBA presented the highest bond strength.
Key Words: endodontics, root-end filling materials, bond strength, push-out.

\section{Introduction}

Selection of a root-end filling material that has adequate physicochemical properties and fulfills the criteria of biocompatibility, cytotoxicity, apical seal and marginal adaptation is of utmost importance for a good clinical prognosis. Among the physicochemical properties, adhesiveness to intraradicular dentin is of particular interest because root-end filling materials must be able to remain adapted to the dentin walls when the teeth are subjected to mechanical forces occurring during function or operative and surgical procedures $(1,2)$.

However, there is not a specific methodology for evaluating the bond strength of root-end filling materials and, for this reason, the same specimen preparation protocol and testing standards originally designed for root canal sealers through push-out test (3-6) have been employed in retrofilling research as well. In view of this, as a rule, the bond strength of root-end filling materials to root dentin is tested using canal-filled slices of the middle root third (1,2,7-11).

Considering that, testing methods in dentistry should attempt to reproduce the conditions in which materials are used in order to predict their clinical performance as close as possible, the bond strength of root-end filling materials could be tested in root-end cavities prepared with retrotips. In this study, a new methodology was proposed to evaluate the bond strength of root-end filling materials MTA and Super EBA to root dentin in the apical root third.

\section{Material and Methods}

Human permanent maxillary central incisors stored in $0.1 \%$ thymol solution at $9{ }^{\circ} \mathrm{C}$ were washed in running water for $24 \mathrm{~h}$ to eliminate thymol residues. After being examined macroscopically and radiographed in a mesiodistal direction, 20 teeth were selected on the basis of having a straight, fully formed root with a single canal without calcifications, accentuated curvature or previous endodontic treatment.

The teeth were sectioned horizontally close to the cementoenamel junction with a diamond disc under constant water cooling to obtain 16-mm long roots. Root canal length was determined with a size $15 \mathrm{~K}$-file (Maillefer, Ballaigues, Switzerland) introduced passively into the canal until its tip was visible at the apical foramen. Working length was calculated by subtracting $1 \mathrm{~mm}$ from canal length. The canals were prepared according to the step-down technique with K-files up to \#80 (Maillefer) inserted in a handpiece with alternating motion (NSK, Kanuma, Tochigi, Japan). K-files \#80 and \#90 and Gates-Glidden drills \#3, \#4 and \#5 (Maillefer) were used to complete the preparation of canals according to a step-back instrumentation. Canals were irrigated with $2 \mathrm{~mL}$ of $1 \% \mathrm{NaOCl}$ at each change of 
files and drills, and final irrigation was performed with 2 $\mathrm{mL}$ of $17 \%$ EDTA for 5 minutes followed by $5 \mathrm{~mL}$ of distilled water. The canals were dried with absorbent paper points.

After biomechanical preparation, the roots were sectioned transversally at two points: $2 \mathrm{~mm}$ short of the apical foramen (which is the level of apicoectomy) and $4 \mathrm{~mm}$ coronally to this point. The apical root third cylinders obtained were included individually in clear autopolymerizing acrylic resin inside aluminum rings (16 $\mathrm{mm}$ diameter and $4 \mathrm{~mm}$ high) for fabrication of specimens.

The root-end cavities were prepared with a diamond ultrasonic retrotip (ST12D-Mani; Mani, Inc. Takanezawa, Tochigi-Ken, Japan) coupled to a ultrasound unit (U.S. Profi II-AS; Dabi Atlante, Ribeirão Peto, SP, Brazil) set at power 3 , under constant cooling with distilled and deionized water. A custom-made device was used to maintain the position of the specimens at $45^{\circ}$ to the horizontal plane during preparation and restoration of the root-end cavities stainless steel (Fig. 1). Root-end cavities with standardized dimensions (1.5 $\mathrm{mm}$ diameter and $2 \mathrm{~mm}$ deep) were prepared by making intermittent forward-backward movements with the retrotip, with penetration limited to $2 / 3$ of its active part (Fig. 2A). The root-end cavities were rinsed with $2 \mathrm{~mL}$ of saline using a NaviTip needle (Ultradent Products Inc., South Jordan, UT, USA) attached to a syringe and dried with absorbent paper cones.

The specimens were divided into two groups $(\mathrm{n}=$ 10) according to the root-end filling materials used for restoration of root-end cavities: MTA (Angelus, Londrina, PR, Brazil) and Super EBA (Bosworth Co, Skokie, IL, USA). The materials were prepared according to the manufacturers.

In each specimen, a master gutta-percha cone \#80 was tug-backed at the limit between the root-end cavity and the canal, and the root-end filling material was inserted into the root-end cavity with an amalgam carrier, condensed with appropriate-size condensers and burnished (Fig. 2B). After a period three times longer than the setting time of each sealer, the gutta-percha cone was removed from the canal. The specimen was then fixed in an Instron 4444 universal testing machine (Instron Corp., Canton, MA, USA) in such a way that the root-end filling faced downwards and was aligned to the shaft, which would exert the load on the sealer. A stainless steel shaft $1 \mathrm{~mm}$ diameter and $5 \mathrm{~mm}$ long) was inserted in the space previously occupied by the gutta-percha cone and run at a crosshead speed of $1 \mathrm{~mm} / \mathrm{min}$ until pushing out the root-end filling
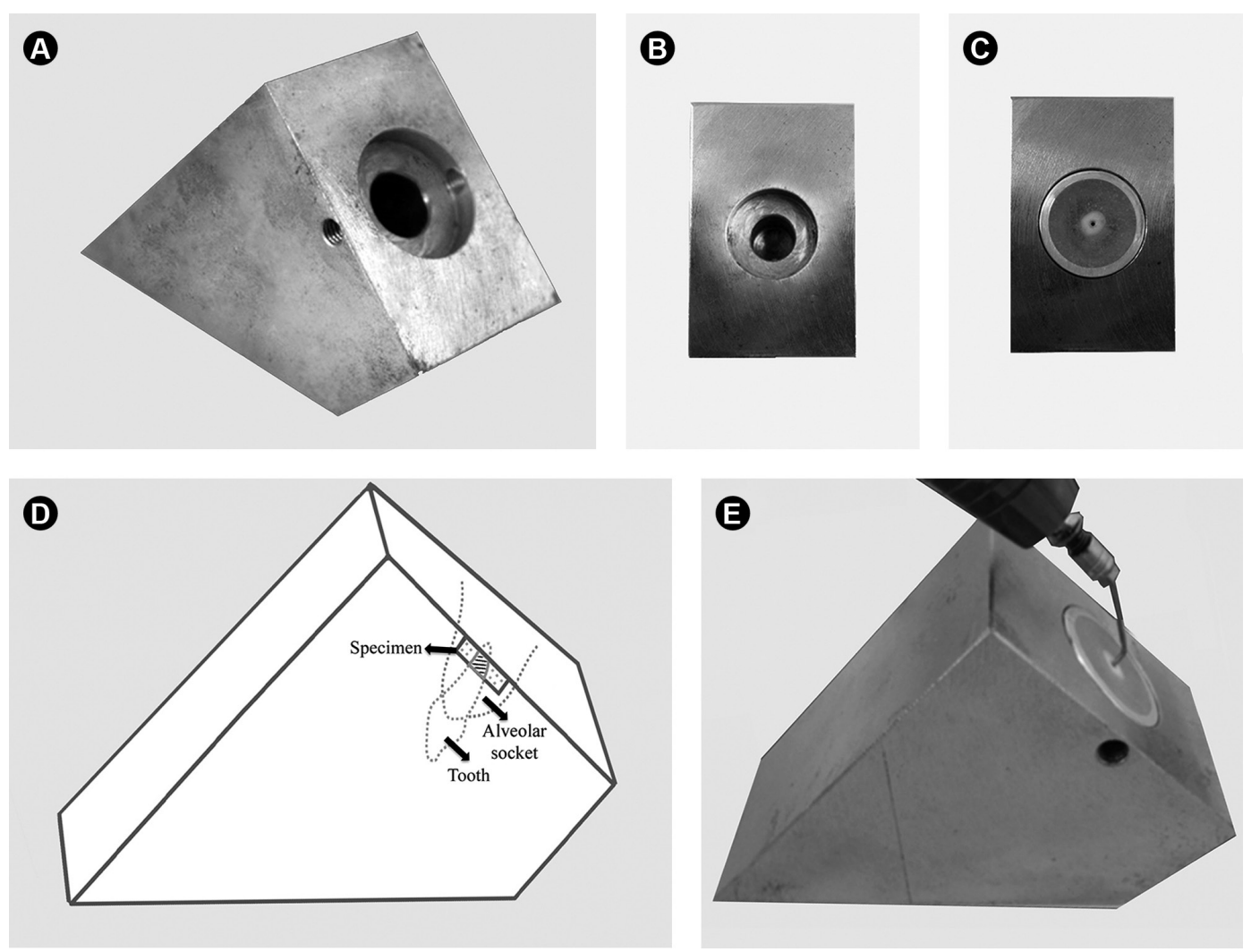

Figure 1. Device designed to standardize the position of the specimens at $45^{\circ}$ to the horizontal plane during preparation and restoration of the root-end cavities. A. Lateral view. B. Frontal view showing the slot to accommodate the specimen. C. Frontal view with the specimen placed inside the device slot. D. Schematic drawing showing the specimen in the device, simulation of the tooth and alveolar socket (dotted lines) and the specimen with the 4-mmthick root cylinder (crosshatch area). E. Specimen positioned at $45^{\circ}$ to the horizontal plane and ultrasonic retrotip positioned at $90^{\circ}$ to apical root third. 
material in a crown-down direction (Fig. 2C). The force needed to dislodge the root-end filling material (F) (in $\mathrm{kN}$ ) was transformed into tension ( $\sigma$; in $\mathrm{MPa}$ ) by dividing the force by the adhesive area of the root-end filling material $\left(S_{L} ;\right.$ in $\left.\mathrm{mm}^{2}\right)$, using the following equation: $\sigma=$ $\mathrm{F} / \mathrm{S}_{\mathrm{L}}$. $\mathrm{S}_{\mathrm{L}}$ was calculated using the following equation: $\mathrm{S}_{\mathrm{L}}=$ $\pi D g+\left(\pi D^{2} / 4-\pi d^{2} / 4\right)$, where $\pi=3.14 ; D=$ mean diameter of the retrofilling $(\mathrm{mm}) ; d=$ mean diameter of the root canal $(\mathrm{mm}) ; \mathrm{g}=$ depth of the retrofilling $(\mathrm{mm})$. Data were subjected to statistical analysis by two-way ANOVA ( $\alpha=5 \%)$ using the GraphPad InStat software (GraphPad Software Inc., San Diego, CA, USA).

After the test, the specimens were cleaved and examined

\section{A}
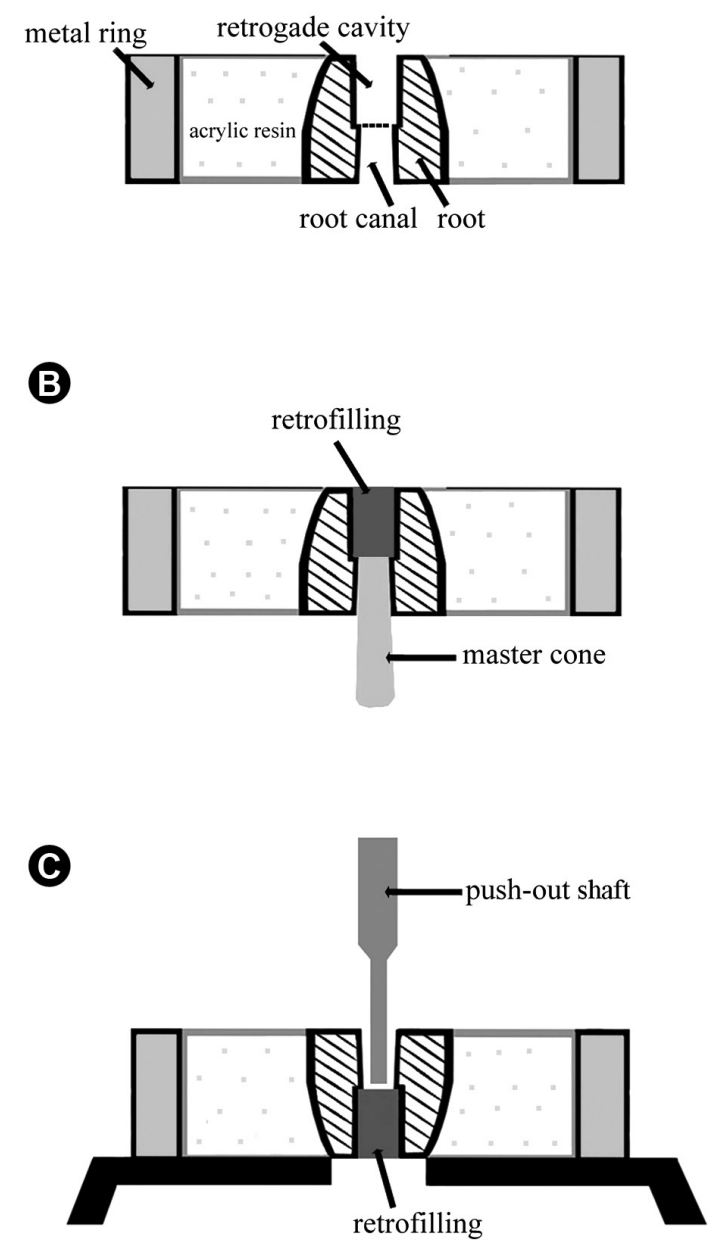

Figure 2. Schematic drawing of specimen preparation and push-out test. A: Four-millimeter-thick root cylinder embedded in acrylic resin, with the root-end cavity and apical portion of the canal. B: Restored root-end cavity and gutta-percha cone tug-backed at the limit between the root canal and the retrofilling. C: Simulation of the push-out test. The specimen is turned downward in relation to images $A$ and $B$, and the testing shaft is inserted in the space previously occupied by the gutta-percha to push out the root-end filling material in a crown-down direction. in a stereomicroscope (ZEISS Stemi 2000-C, Germany) at $25 \times$ magnification to evaluate the failure modes (adhesive, cohesive, mixed) that occurred owing to the displacement of the material from the specimen.

\section{Results}

Super EBA $(6.03 \pm 1.31)$ presented significantly higher bond strength $(p<0.05)$ than MTA $(1.81 \pm 0.45)$. The analysis of failure modes after debonding showed predominance of cohesive failure for Super EBA and mixed failures for MTA.

\section{Discussion}

So far no specific methodology is available for testing the bond strength of root-end filling materials to root dentin and all studies derive their results from the push-out test originally designed for root canal sealers $(1,2,8-10)$. Middle root third slices have been frequently used as a substrate for evaluating the bond strength of root-end filling materials $(1,2,8-11)$, without considering the fact that the density, diameter and number of dentinal tubules in this region are greater than in the apical third (12). Since adhesiveness is directly related to the interaction of the material with dentin surface (4), this difference in the test substrate could result in over or underrepresentation of the bond strength of root-end filling materials (13).

In the present study, the new methodology was proposed in an attempt to provide a more accurate method for assessing the bond strength of root-end filling materials to root-end cavity walls. Materials routinely used for retrofilling were evaluated. In this method, the specimen was prepared in the apical root third and a custom-made device was used to maintain the specimens at $45^{\circ}$ to the horizontal plane during the preparation and restoration of root-end cavity because of the position of the maxillary central incisors in the dental arch. This angle can be changed accordingly for maxillary and mandibular teeth. Likewise, the root-end cavities were prepared with diamond ultrasonic retrotips in the present study, but this methodology can be used to evaluate the bond strength of root-end filling materials to root-end cavities prepared with other tips or laser (14).

Another of the advantages of this methodology is that the shaft is introduced through the coronal portion of the specimen, which means that retrofilling is pushed in a crown-apex direction, with the force starting from the deepest root-end cavity or material base. This modification in the test specimen allows measuring the actual bond strength of the root-end filling material to root-end cavity walls, along the entire cavity extension.

Super EBA is an improved zinc oxide and eugenolbased sealer, which has good sealing ability (15) and its characteristics are not much influenced by moisture (16). 
This compact material is formed by regular and small particles (16) that promote micro-retention of sealer surface during burnishing, which is beneficial to the adaptation of the material to root dentin (17) and could explain the bond strength values and cohesive failure modes observed in this study. MTA is a biomaterial with tissue compatibility $(8,18)$, low cytotoxicity (19), alkaline $\mathrm{pH}(20)$ and good marginal adaptation (21), In the present study, MTA presented lower bond strength to root-end dentin than Super EBA, and the debonded specimens exhibited mixed failures, since after the setting reaction the apatite formation occurs on the surface of the MTA, which creates a structure similar to the tags, but with lower adherence capacity to dentinal tubules (22). These results are consistent with those of Tobón-Arroyave et al. (17), who observed better marginal adaptation and less infiltration with Super EBA than MTA.

Based on the results obtained with two traditional root-end filling materials (Super EBA and MTA), it may be concluded that preparation and the positioning of the specimens in the proposed testing machine in this study is effective and introduces a new and specific methodology for testing the bond strength of these materials.

\section{Resumo}

Este estudo avaliou a resistência de união de materiais retrobturadores a cavidades retrógradas, usando uma nova metodologia. Vinte incisivos centrais superiores foram submetidos ao preparo biomecânico (lima manual \#80) e seccionadas transversalmente a $2 \mathrm{~mm}$ do ápice e a $4 \mathrm{~mm}$ do primeiro corte. Os cilindros de raizes foram incluídos em resina acrílica e posicionado a $45^{\circ} \mathrm{em}$ relação ao plano horizontal para confecção das retrocavidades com ponta ultrassônica diamantada. Dois grupos $(n=10)$ foram formados de acordo com os cimentos utilizados: MTA e Super EBA. Um cone de guta-percha (\#80) foi travado no limite da retrocavidade com o canal radicular. A retrocavidade foi preenchida e, após o tempo de endurecimento do cimento utilizado, o cone de guta-percha foi removido. Os espécimes foram fixados na máquina universal de ensaios Instron com a retrobturação voltada para baixo. A haste empregada para pressionar o cimento retrobturador no teste de push-out foi inserida no espaço anteriormente ocupado pela guta-percha e acionada com velocidade de cruzeta de $1,0 \mathrm{~mm} / \mathrm{min}$, para extrusão do material retroburador. Os dados foram analisados por meio do teste ANOVA $(\alpha=5 \%)$. 0 cimento Super EBA $(6,03 \pm 1,31)$ apresentou maior resistência de união $(\mathrm{MPa})$ comparado ao cimento MTA $(1,81 \pm 0,45)(p>0,05)$. Houve predomínio de falhas coesivas para o cimento Super EBA e falhas mistas para o MTA. 0 protocolo de preparação das amostras é eficaz e apresenta uma metodologia específica para avaliação da resistência de união de materiais retrobturadores à dentina. Dentre os materiais testados, o cimento Super EBA apresentou a maior resistência de união.

\section{References}

1. Carmona-Reyes JF, MS Felippe, WT Felippe. The biomineralization ability of mineral trioxide aggregate and Portland sealer on dentin enhances the push-out strength. J Endod 2010;36:286-291.

2. Saghiri MA, Shokouhinejad N, Lotfi M, M Aminsobhani, Saghiri AM. Push-out bond strength of mineral trioxide aggregate in the presence of alkaline pH. J Endod 2010;36:1856-1859.

3. Sousa-Neto MD, MA Marchesan, Pécora JD, Junior AB, YT Silva-Sousa, Saquy PC. YAG laser on adhesion of root canal sealers: effect of Er. J Endod 2002;28:185-187.
4. Rached-Junior FJ, AE Souza-Gabriel, Alfredo E, Miranda EC, YT SilvaSousa, Sousa-Neto MD. Bond strength of Epiphany sealer prepared with resinous solvent. J Endod, 2009;35:251-255.

5. Carneiro SM, Sousa-Neto MD, Rached FA Jr, Miranda EC, SR Silva, Silva-Sousa YT. Push-out strength of root fillings with or without thermomechanical compaction. Int Endod J 2012;45:821-8.

6. Vilanova WV, JR Carvalho-Junior, Alfredo E, Sousa-Neto MD, SilvaSousa YT. Effect of intracanal irrigants on the bond strength of resinbased epoxy and methacrylate resin-based sealers to root canal walls. Int Endod J 2012;45:42-48.

7. Hong ST, Bae KS, Baek SH, Kum KY, Shon WJ, Lee W. Effects of root canal irrigants on the push-out strength and hydration behavior of accelerated mineral trioxide aggregate in its early setting phase. J Endod 2010;36:1995-1999.

8. Shokouhinejad N, Nekoofar MH, Iravani A, Kharrazifard MJ, Dummer $\mathrm{PMH}$. Effect of acidic enviromnment on the push-out bond strength of mineral trioxide aggregate. J Endod 2010a;36:871-874.

9. Shahi S, Rahimi S, Yavari HR, Samiei M, Janani M, Bahari M et al.. Effects of various mixing techniques on push-out bond strengths of white mineral trioxide aggregate. J Endod 2012;38:501-504.

10. Guneser MB, MB Akbulut, Eldeniz, AU. Effect of various endodontic irrigants on the push-out bond strength of conventional and Biodentine root perforation repair materials. J Endod 2013;39:380-4.

11. Saghiri MA, Garcia-Godoy F, Gutmann JL, Lotfi M, Asatourian A, Ahmadi $H$. Push-out bond strength of the nano-modified mineral trioxide aggregate. Dent Traumatol 2013;29:323-327.

12. Mjör IA, Smith MR, Ferrari M, Mannocci $F$. The structure of dentine in the apical region of human teeth. Int Endod J 2001;34:346-353.

13. Leloup G, DHoore W, Bouter D, M Degrange, Vreven J. Metaanalytical review of factors Involved in dentin adherence. J Dent Res 2001;80:1605-1614.

14. Shokouhinejad N, Razmi H, Fekrazad R, Asgary S, Neshati A, Assadian $\mathrm{H}$ et al. Push-out bond strength of two root-end filling materials in root-end cavities prepared by $\mathrm{Er}, \mathrm{Cr}$ : YSGG laser or ultrasonic technique. Aust Dent J 2010b;38:113-117.

15. Wälivaara $A D$, Abrahamsson $P$, Fogelin $M$, Isaksson S. Super-EBA and IRM root-end fillings those in periapical surgery with ultrasonic preparation: a prospective randomized clinical study of 206 consecutive teeth. Oral Surg Oral Med Oral Pathol Oral Radiol Endod $2011 ; 112: 258-263$

16. Rhim AT, Huh SY, Ahn SJ, Abbott PV, Kim CS, Park HS. Comparison of the microhardness and morphology of five different retrograde filling materials in aqueous and dry conditions. Scanning 2012;34:359-366.

17. Tobón-Arroyave SI, Restrepo-Pérez MM, Arismendi-Echavarria JA, Velásquez Restrepo Z, Marín-Botero ML, Garcia-Dorado JV. Ex vivo microscopic assessment of factors affecting the quality of apical seal created by root-end fillings. Int Endod J 2007;40:590-602.

18. Holland R, Souza V, Murata SS, Nery MJ, Bernabé PF, Otoboni-Filho JA et al.. Healing process of dog dental pulp after pulpotomy and pulp covering with mineral trioxide aggregate or Portland sealer. Braz Dent J 2001;12:109-113.

19. Badr AE. Marginal adaptation and cytotoxicity of bone sealer Compared with mineral trioxide aggregate and amalgam root-end filling the materials J Endod 2010;36:1056-1060.

20. Torabinejad M, Hong CU, McDonald F, Pitt Ford TR. Physical and chemical properties of a new root-end filling material. J Endod 1995;21:349-353.

21. Torabinejad M, Smith PW, Kettering JD, Pitt Ford TR. Comparative investigation of marginal adaptation of mineral trioxide aggregate and other commonly used root end filling materials. J Endod 1995;21:295299.

21. Sagsen $B$, Ustün $Y$, Demirbuga $S$, Pala K. Push-out bond strength of two new calcium silicate-based endodontic sealers to root canal dentine. Int Endod J 2011;44:1088-1091. 